\title{
HUMAN IDENTIFICATION AND ANALYSIS OF DNA IN BONES
}

\author{
Edna Sadayo Miazato Iwamura, José Arnaldo Soares-Vieira and Daniel Romero \\ Muñoz
}

IWAMURA ESM et al. Human identification and analysis of DNA in bones. Rev. Hosp. Clin. Fac. Med. S. Paulo 59(6):383$388,2004$.

The introduction of molecular biology techniques, especially of DNA analysis, for human identification is a recent advance in legal medicine. Substantial effort has continuously been made in an attempt to identify cadavers and human remains after wars, socio-political problems and mass disasters. In addition, because of the social dynamics of large cities, there are always cases of missing people, as well as unidentified cadavers and human remains that are found. In the last few years, there has also been an increase in requests for exhumation of human remains in order to determine genetic relationships in civil suits and court action. The authors provide an extensive review of the literature regarding the use of this new methodology for human identification of ancient or recent bones.

KEYWORDS: Bone. Pathology. DNA analysis. Ancient DNA. Legal medicine. Forensic science.

Substantial and relevant efforts to identify cadavers and human remains after wars, socio-political disturbances and mass disasters have been continuously made and reported. ${ }^{1,2,3,4,5}$ However, those efforts are not restricted only to identification of cases of catastrophes. Because of the social dynamics of modern societies, there are always families looking for missing persons. On the other hand, it is not rare to have unidentified cadavers and human remains in Forensic Medicine Institutions, according to the São Paulo Forensic Medicine Institutions statistics (data not shown). In addition to these cases, in previous years there has been an increase in solicitation for collection of biological samples from exhumed human remains, mainly for genetic investigations of paternity in civil processes. ${ }^{6,7}$
The detection of deoxyribonucleic acid (DNA) polymorphism has been a powerful tool in identification-tests, since its first use in forensic casework investigation, by Jeffreys et al. ${ }^{8}$ (1985). The development of the technology for obtaining the DNA polymorphisms and their validation studies has been very rapid.

However, some factors reduce the power of these tests. In cadavers, DNA degrades very quickly, even in early postmortem periods. The degradation - of soft tissues - is particularly evident after short intervals of time, a conse-

From the Department of Forensic Medicine, Medical Ethics, Social and Work Medicine, Faculty of Medicine, University of São Paulo São Paulo/SP, Brazil.

E-mail: eiwamura@usp.br

Received for publication on April 27, 2004.

Accepted for publication on July 13, 2004. quence of the rapid bacterial increase that is natural in decomposing corpses, especially in those that are exposed to hot temperatures in tropical countries like Brazil ${ }^{6}$. Another common problem is the presence of inhibitors of DNA analysis that could be present. ${ }^{9,10}$

High molecular weight DNA, that is, that which can be analyzed, in human remains or in recent postmortem material, is very scarce due to the degradation of genetic material. Exogenous agents, like microorganisms, humidity and many organic compounds, to which the corpses were exposed, also reduce the amount of informative DNA available. Because of this, bones have been shown to be very useful because of their long preservation. For genetic study, through the DNA from bones in this particular condition, the use of the small size loci 
amplified by polymerase chain reaction (PCR) is necessary, with the short tandem repeat (STR) loci being most convenient. ${ }^{11}$

\section{Nuclear DNA studies in human bones}

Since the paper by Hochmeister et al. ${ }^{12}$ (1991) reporting the use of DNA extracted from human femoral bone of a corpse submerged 18 months under water and a 11-year-old mummifiedcorpse, using RFLP and VNTR loci amplified by PCR, as well HLA DQ A1, other studies in the literature report using restriction fragment length polymorphisms (RFLP), short tandem repeat (STR) and amelogenin typing kits, PCR amplified sequences of the HLA DRB1 gene, and PM Amplitype kits with bones using different methods of extraction. $5,13,14,15,16,17,18,19,20$

The identity of the Romanov family (Czar Nicolas II, Czarina Alexandra and 3 children), killed in 1918 during the Russian revolution, was confirmed using DNA extracted from bone fragments and amplified for 5 STR loci (HUMTH01, HUMVWA31, HUMF13A1, HUMFES/ FPS, and HUMACTPB2) and amelogenin. In this study, in order to establish the relationship of maternal descendants, mitochondrial DNA (mtDNA) analysis was also carried out. ${ }^{17}$

Hochmeister et al. ${ }^{18}$ (1994) described the first case using commercially available kits - the AmpliType ${ }^{\mathrm{O}}$ PM PCR kit and the GenePrintÔ STR Triplex kit - confirming the identity of human remains found in a wooded area, about 1 year after being reported missing.

Cattaneo et al. ${ }^{14}$ (1995), using back vertebra and a fresh femur head bone in 2 cases that were 3 and 9 months postmortem, describe a saturated sodium acetate precipitation method to remove non-DNA material, and subsequent positive PCR amplification of the HLA-DRB1.
In 1997, the same authors analyzed 32 skeletons using sodium acetate, magnetic-beads, glass-milk extraction methods, and PCR amplification for HLA DPB1 (327 pb), amelogenin $(106 / 112 \mathrm{pb})$, and mtDNA loci. The bone samples analyzed were from $6 \mathrm{fe}-$ mur heads from surgeries, 4 femur heads that were 3 to 6 years postmortem, and 22 samples of vertebral bodies 3 to 43 years postmortem. The best amplification was that of the mtDNA, followed by HLA DPB1 that amplified at the same frequency of the amelogenin loci; and amplification was possible in 11 of a total of 32 skeletons. ${ }^{15}$

In an experimental study, Rankin et al..$^{19}$ (1996) used cortical bones from human femurs removed in an autopsy. These femur fragments were submitted to immersion in water, buried $50 \mathrm{~cm}$ in the soil and exposed to the surface in a desert environment. The samples were collected and analyzed after 2, 4, 8 , and 12 weeks of treatment as mentioned above. To extract the DNA, phenol/chloroform/isoamylic alcohol was used. The DNA was quantified and analyzed by RFLP. The results showed that the DNA extracted from bones exposed to the surface in the desert were in the best condition for forensic identification, and the worst was the DNA extracted from fragments immersed in water.

Among 61 Bosnia and Herzegovina war victims, only 3 (1 year and a $1 / 2$ years postmortem) were identified by typing the HLA DQA1 and PM loci, using DNA obtained from 5 to 20 grams of long bone samples, resulting in about $100 \mathrm{ng}$ of DNA per gram of bone. ${ }^{5}$

Evison et al. ${ }^{16}$ (1997) analyzed human bone samples from 1986 to 1994 in forensic cases or exhumed material that had been buried from 1904 to 1984 , as well as from human teeth and blood stains that were 3 months to 91 years old. DNA extraction of those samples was carried out using the silica method. After this, the amplification and analysis of amelogenin, HLA-DPB 1 gene, and mtDNA sequences were performed. There was no correlation between the ages of specimens and the degree of DNA preservation.

Yamamoto et al. ${ }^{20}$ (1998) described in a case report that the remains of a $1 \frac{1}{2}$-year-old baby were found in an apartment 16 years after his death. The skeletal DNA was extracted with phenol/chloroform and was successfully analyzed for 3 loci in the HLA class II region (HLA-DQA1, -DPB1, and DRB1), 5 loci with the AmpliType PM kit (LDLR, GYPA, HBGG, D7S8, and GC), 5 STR loci (LPL, vWA, F13B, TH01, and TPOX), and the D-loop region in the mtDNA.

The use of bones and human remains as sources for detection of DNA polymorphism is a relatively recent advance in forensic identification. A common problem with this kind of analysis is the preservation of DNA. We know that in addition to decomposition by bacteria and other microorganisms, the simultaneous exposure to environmental agents results in DNA degradation in postmortem tissues.

In the city of São Paulo, forensic identification case studies of human remains are usually of 2 types: a) human remains found in different degrees of decomposition and b) human remains exhumed from public or private cemeteries. The state of preservation varies from putrefying cadavers but still complete, to bones with little or no soft tissues. ${ }^{6}$

In the literature, few studies report the problem of the imperative need for cleaning putrefying human remains. According to EVISON et al. ${ }^{16}$ (1997) the pre-fixative $10 \%$ formalin solution preserves high molecular weight DNA fragments, but at the same time, makes its purification more difficult. 


\section{Mitochondrial DNA (mtDNA) study in human bones}

The studies of human bones through the mtDNA could help in the identification of human skeletal remains, as well as clarify historical past events. ${ }^{1,17,21-27}$

The mtDNA extracted from human bones (human femur obtained from a cemetery, about 750 years old, recent tibia from a skeleton buried in Argentina for about 13 years, a fibula from Polynesia dated before 1778) as well as animal bones (pig bones from 1545) and amplified by PCR demonstrated that significant amounts of genetic information could survive for long periods of time. All samples were collected from excavations and stored in boxes for many years. ${ }^{28}$

Bone fragments of pre-Colombian native Amerindian skeletons between 500 to 4000 years old, belonging to the Emílio Goeldi Pará Museum collection (Brasil), were used for the analysis of mtDNA. From the total of 26 individuals, 18 could be positively analyzed. ${ }^{25}$

The analyses of mtDNA and STR were carried out with success on the skeletal remains of an adult woman from the Cuban Ciboney culture holding a child (the age of these remains was estimated at 2,220 \pm 80 years). Based on the results, the authors proposed the South American origin of preColumbian Antilles populations and possible infanticide practices in these populations. This constituted the first report of DNA analysis of the ancient pre-Columbian Cuban population. ${ }^{24}$

The mtDNA and the X-Y homologous gene amelogenin were analyzed to identify the family of Prince Branciforte Barresi, 2 of his children, his brother, and another juvenile member of the family, who lived between the 16th and 17th century (there are reports that the remains found in Sicily date from 1622 ). Molecular ge- netic analyses were consistent with the historical expectation, although they did not directly demonstrate that these are in fact the remains of the Prince and his relatives, due to the impossibility of obtaining the DNA from living maternal relatives of the Prince. All the bones appeared to be in good preservation externally, and the microstructures were perfectly preserved. ${ }^{26}$

The authenticity of the identity of the last Tsar Nicolas Romanov II and Tsarina Alexandra, killed in 1918, was demonstrated by comparing the mtDNA sequence of the maternal relatives, from the grand Duke of Russia Georgij Romanov (death in 1889) and Prince Phillip, mtDNA sequences being obtained from bones and blood, respectively. ${ }^{27}$

Twenty-four years after the Vietnam War, human skeletal remains belonging to an American military service member were identified by the analysis of mtDNA. ${ }^{23}$

In Argentina, about 340 skeletons (people killed between 1976 to 1983 during the military dictatorial period) were found. A very small number of these individuals were identified by traditional forensic methods, and only 1 family was identified by the mtDNA analysis. The DNA typing methods, $Y$ chromosome-specific STR loci and and amplification of autosomal microsatellites using nested primers, were used in an attempt to identify more individuals. ${ }^{1}$

\section{Nuclear DNA study in ancient human bones and teeth}

Ancient DNA - as characterized by Hummel et al ${ }^{29}$ (1993) - obtained from human remains is, in general, severely damaged chemically or physically. However, during the past few years, ancient nuclear DNA studies from human remains of up to 8,000 years have been described with success and controversy. ${ }^{10,30,31,32,33,34,35,36,37}$
Cortical and cranial bones, as well as teeth, were found to provide sufficiently preserved DNA for analysis. The sex was determined from skeletal remains of 18 individuals, including young children, out of 22 examined from periods ranging from 200 to around 8,000 years. The success of retrieval of amplifiable DNA was not reported with regard to the period or to the burial site. ${ }^{38}$

The alleles of the STR locus vWA31A were amplified from bones and teeth from a medieval burial site in Germany using PCR. The DNA results of 76 individuals showed similarity with the allelic frequencies between past and modern populations. ${ }^{39}$

The 3 STR loci, HUMPES/FPS, HUMTH01, and HUMvWA31A, were selected to type 10 samples of spongy bones from individuals who were buried for 1 year, and 8 samples of femur heads from the XII-XIII century Basque Country population. In the first group of bones (1-year postmortem), the total amount of DNA extracted and spectrophotometrically measured was $25 \mathrm{mg}$ per gram of spongy bone tissue. Of this, human DNA was on average $50 \mathrm{ng}$ per gram of spongy bone tissue. From the XII-XIII century group, 5 individuals could be successfully typed, with repetition of the results being more difficult with the locus HUMVWA31A than with locus HUMTH01. ${ }^{40}$

Three microsatellites (IVS8CA, VS17BTA, and IVS17BCA) within the cystic fibrosis transmembrane conductance regulator gene were analyzed in 28 samples of DNA from bones and teeth of up to 5,000 years of age. PCR amplification was successful in $71 \%$ of cases. The repeated analysis of each marker produced different genotypes in $97 \%$ of samples, and the same individual genotype was reproduced at least once in $45 \%$ of cases. ${ }^{41}$

To determine the effect of environmental factors on the preservation of DNA, 38 archaeological teeth from 18 
individuals of approximately similar age (900 to 2000 years BC), but greatly differing in terms of site milieu, were analyzed for DNA content. The environment of the location of the samples was analyzed regarding temperature, humidity, $\mathrm{pH}$ value, geochemical properties of the soil, the amount of organic substances, and the degree of microbial infestation of the respective soil. The relative DNA content in those samples was established by determining the rate of successful PCR amplifications. The STR loci HUMVWA31A, HUMTH01, HUMFES/ FPS, and amelogenin were analyzed. Differences in quantity and quality of the results are attributed to the respective prevailing environmental factors or to respective storage conditions. ${ }^{9}$ For example: specimens stored at room temperature for 16 years yielded almost as many amplification products as the samples immediately stored in a lab freezer. But the genotypes of the samples that were stored at room temperature for 16 years were less reproducible than the immediately deepfrozen ( $-20^{\circ} \mathrm{C}$ samples).

Schultes et al. ${ }^{42}$ (1999) report that, for the first time, the amplification of the STR loci of the Y chromosome was possible in historical and prehistoric bones of 3,000 years of age.

The applicability of the amplification of 9 STR loci and amelogenin was shown by typing bones and teeth, from few months to up to 3,000 years of age, using the Ampf/STR Profiler Plus.
This method proved to be efficient in the analysis of ancient degraded DNA, in addition to the positive aspect of the utilization of minimal amounts of the sample. ${ }^{29}$

Recently, Clisson et al. ${ }^{31}$ (2002) analyzed bone and frozen tissue samples of 2 human remains more than 2000 years old, found in Kazaquistan, by using nuclear STR and mtDNA.

According to Handt et al. ${ }^{29}$ (1994), molecular archaeology, in which the DNA sequences recovered from specimens in museum collections and archaeological sites are studied, presents a problem that is unique in the field of molecular biology : the difficulty of verifying and reproducing results by repetition. Some reasons are technical and derive from the low numbers of copies and the extent of damage of the ancient DNA molecules. Other are the unique nature of extracted DNA.

The results obtained from the analysis of DNA from ancient human bone tissue, horse bones, and mummified soft tissues (from 40 years to 50,000 years old), indicate that all samples with low levels of damage and from which the DNA could be amplified originated from regions where low temperatures have prevailed throughout the burial period of the specimens. $^{29,33}$

\section{CONCLUSION}

In ancient specimens, that is, ar- chaeological remains, the quantitative and qualitative differences in results are attributed to the respective prevalence of environmental factors or to the storage conditions. Brief storage at room temperature does not affect the amount of amplifiable DNA, but affects the reproducibility of the results. Storage for long periods in an unfrozen state reduces the amount and the reproducibility of DNA amplifications. Low humidity, low temperature, and the absence of microorganisms favor the preservation of DNA. Data show that there is no correlation between DNA preservation and time. Favorable conditions can slow down chemical and physical damage to a certain extent, allowing detection and analyses of all kinds of DNA after thousands of years.

In studies of detection of DNA polymorphism using human bones a few months old to some years postmortem, analysis has not met with good success, and only a few cases of successfully positive identification have been reported. ${ }^{6}$ In addition to the difficulty of verifying and reproducing the results, an inconsistency with regard to the results of DNA analysis from exhumed bones has been observed.

According to the data of some authors, ${ }^{2,6}$ identification of cadavers and human remains represents an increasing problem in countries of the European Union and Latin America and probably world-wide.

\section{RESUMO}

IWAMURA ESM e col. Identificação Humana e Análise de DNA em Ossos. Rev. Hosp. Clin. Fac. Med. S. Paulo 59(6):383-388, 2004.

A introdução das técnicas de biologia molecular, ou seja a análise de
DNA para identificação humana é um avanço recente na Medicina Legal. A identificação de cadáveres e restos humanos faz-se necessária após guerras, distúrbios sócio-políticos e desastres de massa. Além desses casos, devido à dinâmica social das grandes metrópo- les, existem pessoas desaparecidas e por outro lado, cadáveres e restos humanos sem identificação são encontrados. Nos últimos anos, também tem ocorrido um aumento nas solicitações para coleta de material biológico de restos humanos exumados e destina- 
dos à determinação de vínculo genético em processos civis. Os autores realizam uma extensa revisão da litera- tura sobre a utilização dessas novas metodologias em ossos, antigos ou recentes, para a identificação humana.
UNITERMOS: Osso e ossos. Patologia. DNA/análise. DNA antigo. Medicina Legal.

\section{REFERENCES}

1. Corach D, Sala A, Penacino G, Iannuci N, Bernardi P, Doretti M, et al. Additional approaches to DNA typing of skeletal remains: the search for "missing" persons killed during the last dictatorship in Argentina. Electrophoresis 1997;18:1608-12.

2. Lorente JA, Entrada C, Alvarez C, Arce B, Heinrichs B, Lorente $\mathrm{M}$, et al. Identification of missing persons: the Spanish "Phoenix" Program. Croat Med J 2001;42(3):267-70.

3. Munõz DR. Perícia médico-legal nos desastres de massa; análise metodológica e planejamento para a identificação de vítimas de acidentes aéreos no Brasil [Tese livre-docência]. Faculdade de Medicina da Universidade de São Paulo. São Paulo; 1999.

4. Olaisen B, Stenersen M, Mevag B. Identification by DNA analysis of the victims of the August 1996 Spitsbergen civil aircraft disaster. Nature Genet 1997;15:402-5.

5. Primorac D, Andelinovic S, Defini-Gojanovic M, Drmic I, Rezic $\mathrm{B}$, Baden MM, et al. Identification of war victims from mass graves in Croatia, Bosnia, and Herzegovina by the use of standard forensic methods and DNA typing. J Forensic Sci 1996;41:891-4.

6. Iwamura ESM, Soares-Vieira JA, Oliveira CRGCM, Nascimento SAB, Muñoz DR. A qualitative study of compact bone microstructure and nuclear STR obtained from femur of human remains found on the ground and exhumed 3 years after death. Am J Forensic Med Pathol "no prelo".

7. Melki JAD, Martin CCS, Simões AC. Procedimentos em exumações para investigação de vínculo genético em ossos. Rev Saúde Pública 2001;35:368-74.

8. Jeffreys A.J, Brookfield JFY, Semeonoff R. Positive identification of an immigration test case using human DNA fingerprints. Nature 1985;317:818-9.

9. Burger J, Hummel S, Herrmann B, Henke W. DNA preservation: a microsatellite-DNA study on ancient skeletal remains. Electrophoresis 1999;20:1722-8.

10. Stoneking M. Ancient DNA: how do you know when you have it and what can you do with it? Am J Hum Genet 1995;57:125962.

11. Ruitberg CM, Reeder DJ, Betler JM. STR Base: a short tandem repeat DNA database for the human identity testing community. Nucl Ac Res 2000;29(1):320-2.

12. Hochmeister MN, Bubowle B, Borer UV, Eggmann U, Comey CT, Dirnhofer R. Typing of deoxyribonucleic acid (DNA) extracted form compact bone from human remains. J Forensic Sci 1991;36:1649-61.

13. Alonso A, Andenovic S, Martin P, Sutlovic D, Erceg I, Huffine E, et al. DNA typing from skeletal remains evaluation of multiplex and megaplex STR systems on DNA isolated from bone and teeth samples. Croat Med J 2001;42(3):260-6.
14. Cattaneo C, Smillie DM, Gelsthorpe K, Piccinene A, Gelsthorpe AR, Sokol RJ. A simple method for extracting DNA from old skeletal material. Forensic Sci Int 1995;74:167-74.

15. Cattaneo OC, Craig OE, James NT, Sokol RJ. Comparison of three DNA extraction methods on bone and blood stains up to 43 years old and amplification of three different gene sequences. J Forensic Sci 1997;42:1126-35.

16. Evison MP, Smillie DM, Chamberlain AT. Extraction of singlecopy nuclear DNA from forensic specimens with a variety of postmortem histories. J Forensic Sci 1997;42:1032-8.

17. Gill P, Ivanov PL, Kipton C, Piercy R, Benson N, Tully G, et al. Identification of the remains of the Romanov family by DNA analysis. Nature Genet 1994;6:130-5

18. Hochmeister MN, Budowle B, Borer UV, Rudin O, Bohnert M, Dirnhofer R. Confirmation of the identify of human skeletal remains using multiplex PCR amplification and typing kits. J Forensic Sci 1994;40:701-5.

19. Rankin, DR, Narveson SD, Birkby WH, LAI J. Restriction fragment length polymorphism (RFLP) analysis on DNA from human compact bone. J Forensic Sci 1996;41:40-6.

20. Yamamoto T, Uchihi R, Kojima T, Nozawa H, Huang XL, Tamaki $\mathrm{K}$, et al. Maternal identification from skeletal remains of an infant kept by the alleged mother for 16 years with DNA typing. J Forensic Sci 1998;43:701-5.

21. Boles TC, Snow CC, Stover E. Forensic DNA testing on skeletal remains from mass graves: a pilot project in Guatemala. J Forensic Sci 1995;40:349-55.

22. Hagelberg E, Clegg JB. Isolation and characterization of DNA from archaeological bone. Proc R Soc Lond B 1991;244:4550 .

23. Holland MM, Fisher DL, Mitchell LG, Rodriguez WC, Canik JJ, Merril CR, et al. Mitochondrial DNA sequence analysis of human skeletal remains: identification of remains from the Vietnam War. J Forensic Sci 1993;38:542-53.

24. Lleonart R, Riego E, Rodriguez Suárez R, Traviesso Ruiz R, De La Fuente J. Analyses of DNA from ancient bones of a preColumbian Cuban woman and a child. Genet Mol Biol 1999;22:285-9.

25. Ribeiro-dos-Santos A, Santos SEB, Machado AL, Guapindaia V, Zago MA. Heterogeneity of mitochondrial DNA haplotypes in pre-Columbian natives of the Amazon Region. Am J Phys Anthropol 1996;101:29-37.

26. Rickards O, Martínez-Labarga C, Favaro M, Frezza D, Malleoni F. DNA analyzes of the remains of the Prince Branciforte Barresi family. Int J Legal Med 2001;114:141-6. 
27. Ivanov PL, Wadhams MJ, Roby RK, Holland MM, Weedn VW, Parsons TJ. Mitochondrial DNA sequence heteroplasmy in the Grand Duke of Russia Georgij Romanov establishes the authenticity of the remains of Tsar Nicholas II. Nat Genet 1996;12(4):417-20.

28. Hummel S, Schultes T, Bramanti B, Herrmann B. Ancient DNA profiling by megaplex amplications. Electrophoresis 1999;20:1717-21.

29. Handt O, Krings M, Ward RH, Päabo S. The retrieval of ancient human DNA sequences. Am J Hum Genet. 1996;59:368-76.

30. Béraudd-Colomb E, Roubin R, Martin J, Maroc N, Gardeisen A, Traubuchet G, et al. Reply to Cooper. Am J Hum Genet [letter] 1997;60:1002-3.

31. Clisson I, Keysr C, Francfort HP, Crubezy E, Samashev Z, Ludes B. Genetic analysis of human remains from a double inhumation in a frozen Kurgan in Kazakhstan (Berel site, Early $3^{\text {rd }}$ Century BC). Int J Legal Med 2002;116:304-8.

32. Cooper A. Reply to Stoneking: ancient DNA - How do you really know when you have it? Am J Hum Genet [letter] 1997;60:1001-2.

33. Höss M, Jaruga P, Zastawny TH, Dizdaroglu M, Päabo S. DNA damage and DNA sequence retrieval from ancient tissues. Nucleic Acids Res 1996;24:1304-7.

34. Lindahl, T. Facts and artifacts of ancient DNA. Cell 1997;98:1-3.

35. Meijer H, Perizonius WRK, Geraedts JPM. Recovery and identification of DNA sequences harboured in preserved ancient human bones. Biochem Biophys Res Common 1992;183:36774.
36. Schmidt T, Hummel S, Herrmann, B. Evidence of contamination in PCR laboratory disposables. Naturwissenschaften 1995;82:423-31.

37. Tuross N. The biochemistry of ancient DNA in bone. Experientia 1994;50:530-5.

38. Faerman M, Filon D, Kahila G, Greenblatt CL, Smith P, Oppenheim A. Sex identification of archaeological human remains based on amplification of the $\mathrm{X}$ and $\mathrm{Y}$ amelogenin alleles. Gene $1995 ; 167: 327-32$.

39. Zierd H, Hummel S, Herrmann B. Amplification of human short tandem repeats from medieval teeth and bone samples. Hum Biol 1996;68:185-9.

40. Pancorbo MM, Castro A, Alonso S; Fernández-Fernández I, Barbero C, Garcia-Orad A, et al. Genetic typing with HUMTH01, HUMVWA31A and HUMFES?FPS short tandem repeat loci, D1S80 variable number tandem repeat locus and HLA-DQa of recent and from XII-XIII centuries spongy bone. Electrophoresis 1995;16:1612-6.

41. Ramos MD, Lalueza C, Girbau E, Pérez-Pérez A, Quevedo S, Turbón D, et al. Amplifying dinucleotide microsatellite loci from bone and tooth samples of up to 5000 years of age: more inconsistency than usefulness. Hum Genet 1995;96:205-12.

42. Schultes T, Hummel S, Herrmann B. Amplification of Y Chromosomal STRs from ancient skeletal material. Hum Gen 1999;104:164-6. 